\title{
Molecular evidence for a single taxon, Anopheles nuneztovari s.l., from two endemic malaria regions in Colombia
}

\author{
Luz Marina Jaramillo', Lina A Gutiérrez¹, Shirley Luckhart², \\ Jan E Conn ${ }^{3,4}$, Margarita M Correa ${ }^{1 /+}$ \\ ${ }^{1}$ Grupo de Microbiología Molecular, Escuela de Microbiología, Universidad de Antioquia, Calle 67 53-108, Lab. 5-430, Medellín, Colombia \\ ${ }^{2}$ Department of Medical Microbiology and Immunology, University of California at Davis, Davis, CA, USA \\ ${ }^{3}$ Griffin Laboratory, Wadsworth Center, New York State Department of Health, NY, USA \\ ${ }^{4}$ Department of Biomedical Sciences, School of Public Health, State University of New York at Albany, Albany, NY, USA
}

To elucidate the Anopheles nuneztovari s.l. taxonomic status at a microgeographic level in four malaria endemic localities from Antioquia and Córdoba, Colombia, fragments of the cytochrome oxidase subunit I (COI) and the white gene were used. The COI analysis showed low genetic differentiation with fixation index $\left(F_{S T}\right)$ levels between

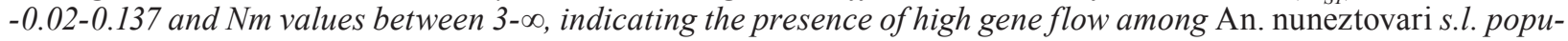
lations from the four localities. The COI network showed a single most common haplotype, type $1(n=55)$, present in all localities, as the likely ancestral haplotype. Analysis of the white gene showed that An. nuneztovari s.l. populations from both departments grouped with haplotypes 19 and 20, which are part of lineage 3 reported previously. The results of the present study suggest that An. nuneztovari s.l. is a single taxon in the area of the present study.

Key words: malaria - Anopheles nuneztovari - white gene - cytochrome oxidase subunit I - Colombia

Malaria is an important public health problem in Colombia, as demonstrated by the fact that, after Brazil, Colombia has the second highest number of malaria cases in Latin America (OPS 2009). In the past 10 years, the departments of Antioquia and Córdoba, where this investigation was carried out, have reported nearly $60 \%$ of the total cases of the country (Rodríguez et al. 2011). There are three main vectors, all in subgenus Nyssorhynchus, reported for Colombia present in endemic areas of these departments, including Anopheles albimanus Wiedemann, Anopheles darlingi Root and Anopheles nuneztovari Gabaldón (Olano et al. 2001).

An. nuneztovari s.l. is distributed from eastern Panamá to northern South America and Amazonia (Mirabello \& Conn 2008) where it presents differences in behaviour (Montoya-Lerma et al. 2011). Brazilian collections of this species have detected natural infection with Plasmodium (Arruda et al. 1986, Tadei et al. 1998), but the role of $A n$. nuneztovari s.l. in Brazil seems to be limited to local malaria transmission (Galardo et al. 2007). Indeed, populations from Brazil are mainly zoophilic and exophagic with a biting peak near sunset (Tadei \& Thatcher 2000). In contrast, in Colombia and Venezuela, An. nuneztovari s.l. is a primary malaria vector (Lounibos \& Conn 2000). Recent studies in northeastern Colombia showed that An. nuneztovari s.l. exhibits anthropophilic and en-

Financial support: CODI-UdeA (8700-074 to MMC), Estrategia para la Sostenibilidad- UdeA 2007-2008 (BUPP E01335 to MMC), NIH (R03AI076710-02 to MMC, AI R01 54139-02 to JEC)

+Corresponding author: mcorrea@quimbaya.udea.edu.co

Received 21 June 2011

Accepted 25 October 2011 dophagic behaviour, with a biting peak between 08:00$11: 00 \mathrm{pm}$ and can be naturally infected with Plasmodium vivax VK247 (Gutiérrez et al. 2009a). In Venezuela, the highest biting activity is close to midnight indoors and outdoors (Rubio-Palis \& Curtis 1992).

Based on morphology, cytology, ecology, behavioural and molecular differences, several authors have suggested that An. nuneztovari s.l is a species complex (summarized in Calado et al. 2008, Montoya-Lerma et al. 2011). Recent white gene analyses described five lineages across its range, with one (lineage 3 ) present in Colombia (Mirabello \& Conn 2008). An. nuneztovari s.l. is characterized by high intraspecific morphological variability and is thus easily misidentified or confounded with other members of the Oswaldoi Group (Calle et al. 2008, Cienfuegos et al. 2008, Gómez et al. 2010). A deeper dissection of this challenging variability resulted in the description of a new morphological form in the Brazilian Amazon (Bergo et al. 2007), later confirmed as Anopheles goeldii Rozeboom and Gabaldón by sequence analysis of internal transcribed spacer (ITS)2, cytochrome oxidase subunit I (COI) and white genes (Calado et al. 2008). Scarpassa and Conn (2011) recently determined that, based on a phylogenetic analysis of $C O I$ gene sequences, samples from the Amazon Basin could be assigned to two well-supported clades. They hypothesize that one of these clades represents An. goeldii and the second clade represents a previously undescribed lineage or taxon in An. nuneztovari s.l.

Few studies have attempted to document the taxonomic status and population structure of An. nuneztovari s.l. in Colombia. One study evaluated phenotypic variation in specimens from western and eastern Colombia and detected high levels of wing spot variation, a key character that is often difficult to assess for proper identification (Ramos et al. 2008). Similarly, morpho- 
metric analysis of female specimens of An. nuneztovari s.l. from Montelíbano (MLT), Córdoba, found high intraspecific variability (Gómez et al. 2010).

Studies using molecular markers have also attempted to clarify the taxonomic status and population structure of An. nuneztovari s.l. from northern and western Colombia. Using random amplified polymorphic DNA (RAPD), Posso et al. (2003) found low levels of genetic differentiation among three populations. Analysis of ITS2 sequences concluded that in Colombia, An. nuneztovari s.l. from both sides of the Andes mountains comprised a single genetic species (Sierra et al. 2004). Given the wide distribution of An. nuneztovari s.l. in Antioquia and Córdoba, this study was conducted to test the hypothesis that a single taxon is present in this region, to assess the genetic variability at a microgeographic level and to identify the white gene lineage(s) present.

\section{MATERIALS AND METHODS}

Mosquito collection and processing - Adult female specimens of An. nuneztovari s.l. were collected between November 2007-February 2010 in El Bagre (BAG), Zaragoza (ZAR) and San Pedro de Urabá (SPU), in the department of Antioquia and in MTL and Puerto Libertador (PTL), in Córdoba (Fig. 1, Table I). The collection protocols and informed consent were reviewed and approved by a Bioethics Committee for Human Research at the University of Antioquia. Mosquitoes were identified by morphological keys (Faran 1980, Faran \& Linthicum 1981, González \& Carrejo 2009). A subset of specimens collected from each field trip is maintained in the University collection. For morphological reference, we retain the wings and legs fixed on slides of a percentage of the specimens. We also maintain photographic records of most specimens that have been processed for molecular analyses.

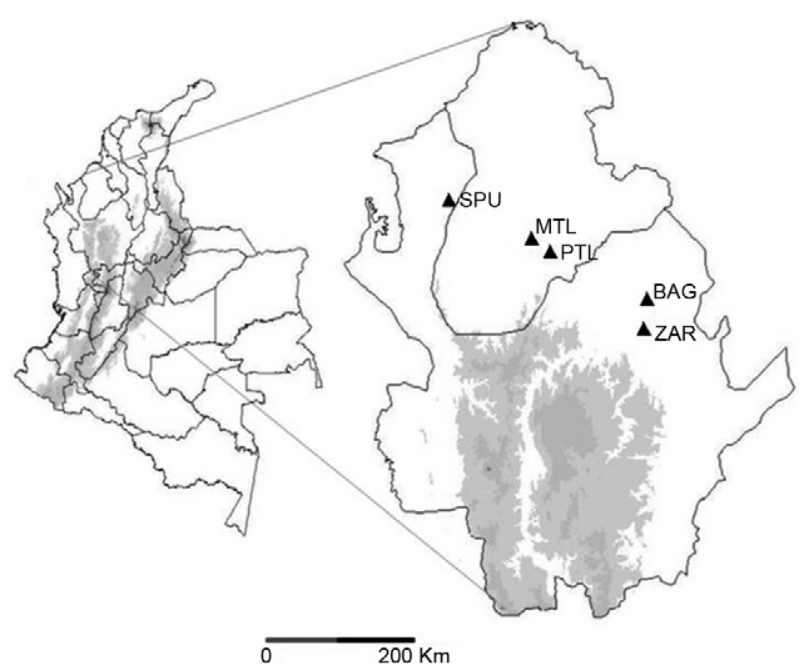

Fig. 1: distribution of collection sites for Anopheles nuneztovari s.l. in Antioquia and Córdoba, Colombia. BAG: El Bagre; MTL: Montelíbano; PTL: Puerto Libertador; SPU: San Pedro de Urabá; ZAR: Zaragoza.
Molecular analyses - Total DNA was extracted from individual mosquito abdomens by a standard protocol (Rosero et al. 2010) used to confirm species identification following a polymerase chain reaction (PCR)-restriction fragment length polymorphism (RFLP)-ITS2 assay developed by our group (Zapata et al. 2007, Cienfuegos et al. 2008, 2011) and then amplified for the COI and white gene fragments as outlined below. A 1,300 bp fragment of the mtDNA COI gene was amplified by PCR using $10 \mu \mathrm{M}$ primers UEA3/UEA10 (Lunt et al. 1996 ) in a $25 \mu \mathrm{L}$ final reaction volume as previously described (Gutiérrez et al. 2010). PCR products were purified using Wizard SV Gel and PCR Clean-up System (Promega, Madison, WI) following the protocol recommended by the manufacturer and sequenced in both directions.

An 800 bp region of the nuclear white gene was amplified using primers WF and W2R in a $25 \mu \mathrm{L}$ PCR reaction with conditions previously described by Mirabello and Conn (2008). Because of allelic variation (Mirabello \& Conn 2008), white gene PCR products were cloned as described in Onyabe and Conn (1999). Five clones corresponding to five specimens from each locality were sequenced. Sequences were edited, assembled by pairwise alignment and then multiple alignments with CLUSTALW were performed using the Geneious software 5.3.4 (Drummond et al. 2011).

Descriptive statistics and population differentiation test - Haplotype and nucleotide diversities of mtDNA COI sequences were obtained using DnaSP version 5.00.07 (Rozas et al. 2003) and Arlequin version 3.11 software (Excoffier et al. 2005). Analysis of molecular variance (AMOVA) was used to evaluate within and among population variation using Arlequin software. The COI haplotype distribution was evaluated by a statistical parsimony network with 95\% support (Clement et al. 2000).

TABLE I

Study sites, dates of collection, coordinates and sample sizes (n) of Anopheles nuneztovari s.l. collected from Antioquia and Córdoba, Colombia

\begin{tabular}{|c|c|c|c|c|}
\hline Municipality & Year & $\begin{array}{l}\text { Month } \\
\text { (number } \\
\text { of days) }\end{array}$ & Coordinates & $\mathrm{n}$ \\
\hline Montelíbano & 2007 & $\begin{array}{c}\text { July (5) } \\
\text { August (2) }\end{array}$ & $7^{\circ} 59^{\prime} \mathrm{N} 75^{\circ} 25^{\prime} \mathrm{W}$ & 29 \\
\hline Puerto Libertador & 2007 & January (6) & $07^{\circ} 43^{\prime} \mathrm{N} 75^{\circ} 51^{\prime} \mathrm{W}$ & 32 \\
\hline El Bagre & 2009 & $\begin{array}{c}\text { March (3) } \\
\text { May (3) }\end{array}$ & $07^{\circ} 35^{\prime} \mathrm{N} 74^{\circ} 49^{\prime} \mathrm{W}$ & 41 \\
\hline Zaragoza & 2008 & $\begin{array}{c}\text { January (1) } \\
\text { March ( 3) } \\
\text { June (1) }\end{array}$ & $07^{\circ} 29^{\prime} \mathrm{N} 74^{\circ} 51^{\prime} \mathrm{W}$ & 8 \\
\hline
\end{tabular}

San Pedro de Urabá 2010 February (5) 06²2'N 75³3’W 37

Total 
Phylogenetic relatedness of An. nuneztovari s.l. populations from Antioquia and Córdoba with populations from South America using white gene sequences - Split networks are successful tools for visualizing incompatible and ambiguous signals and have been used previously for phylogenetics studies (Gutiérrez et al. 2009b, 2010). Therefore, a neighbour-net network was estimated using SplitsTree4 version 4.10 (Huson \& Steel 2004, Huson \& Bryant 2006) for An. nuneztovari s.l. white gene sequences obtained in this study and for those in GenBank corresponding to specimens from Brazil, Bolivia, Surinam, Venezuela and Colombia (accessions EU500727EU500758). Bayesian analysis was carried out using $\mathrm{Mr}$ Bayes v3.1 (Huelsenbeck \& Ronquist 2001), available in Geneious software 5.3.4 (Drummond et al. 2011), using the default HKY85 model and gamma distributions. The settings for the Markov Chain Monte Carlo were four chains running every 100,000 generations.

\section{RESULTS}

An. nuneztovari s.l. genetic variation at the intra-population level - Out of 2,490 Anopheles mosquitoes collected in Antioquia and Córdoba, Colombia, 147 An. nuneztovari s.l. specimens were chosen (Fig. 1, Table I). A 1,180 bp sequence of the COI gene was analyzed. The aligned sequences showed 23 variable sites and 11 that were par- simony informative. The highest nucleotide diversity was detected in SPU $(0.00249+/-0.001315)$ and moderate to lowest diversity was detected in PTL $(0.00172+/$ 0.001120 ). The haplotype diversity (Hd) was highest for SPU (0.8134/-0.0418) and lowest for PTL (0.709+/-0.0578) (Table II). To compare the population pairs using the COI gene, samples from BAG and ZAR were combined. These localities are $11 \mathrm{~km}$ apart and $\mathrm{Nm}$ detected infinite migrants between them. There were 20 unique haplotypes (GenBank accessions JN255752-JN255771), all of which connected parsimoniously. Four haplotypes were shared among all localities. The most widespread haplotype (type $1)$, showed a frequency of $38 \%(55 / 147)$ and was found in all localities. Three other haplotypes were distributed among all localities: type $2(21 \%)$, type $3(12 \%)$ and type $4(10 \%)$. Haplotype 3 was not found in SPU (Table II). There were few private haplotypes (Fig. 2).

Genetic structure and demographic inference - The fixation index $\left(\mathrm{F}_{\mathrm{ST}}\right)$ values estimated for $\mathrm{COI}$ sequences from localities in Antioquia and Córdoba indicated low to moderate genetic differentiation, with values ranging between -0.02-0.137. The number of migrants per generation, $\mathrm{Nm}$, was between $3-\infty$, indicating gene flow among all An. nuneztovari s.l. tested (Table III). AMOVA, based on $C O I$ haplotype frequencies and conducted with all

TABLE II

Shared cytochrome oxidase subunit I (COI) haplotypes and genetic polymorphism statistics for Anopheles nuneztovari s.l. collected in localities of Antioquia and Córdoba, Colombia

\begin{tabular}{|c|c|c|c|c|c|c|}
\hline Locality & $\mathrm{n}$ & COI haplotype & $\begin{array}{c}\text { Segregating } \\
\text { sites } \\
\text { (n) }\end{array}$ & $\begin{array}{l}\text { Haplotype } \\
\text { (h) }\end{array}$ & $\begin{array}{l}\text { Haplotype } \\
\text { diversity } \\
\text { (SD) }\end{array}$ & $\begin{array}{l}\text { Nucleotide } \\
\text { diversity } \\
\text { (SD) }\end{array}$ \\
\hline Montelíbano & 29 & $1(11), 2(5), 3(2), 4(5), 6(2), 8(2)$ & 9 & 8 & $0.807+/-0.5240$ & $0.00189+/-0.001199$ \\
\hline Puerto Libertador & 32 & $1(15), 2(8), 3(1), 4(5), 6(2), 8(2)$ & 7 & 7 & $0.709+/-0.0578$ & $0.00172+/-0.001120$ \\
\hline Total Córdoba & 61 & $1(26), 2(13), 3(13), 4(10), 6(4)$ & 10 & 10 & $0.758+/-0.0397$ & $0.00180+/-0.001128$ \\
\hline San Pedro de Urabá & 37 & 1(10), 2(13), 4(2), 5(6), 6(2), 9(2) & 15 & 10 & $0.8134 /-0.0418$ & $0.00249+/-0.001315$ \\
\hline El Bagre and Zaragoza & 49 & $1(21), 2(5), 3(15), 4(3), 7(2)$ & 9 & 8 & $0.720+/-0.0441$ & $0.00237+/-0.001417$ \\
\hline Total Antioquia & 86 & $1(29), 2(17), 3(15), 4(2), 5(6)$ & 19 & 13 & $0.773+/-0.0280$ & $0.00271+/-0.001445$ \\
\hline Overall Total & 147 & $1(55), 2(230), 3(28), 4(12), 5(6), 6(4)$ & 23 & 20 & $0.781+/-0.0302$ & $0.00234+/-0.001288$ \\
\hline
\end{tabular}

numbers inside parentheses are the frequency of haplotypes by locality. All haplotypes are shared among populations of Antioquia and Córdoba. SD: standard deviation.

TABLE III

Pairwise genetic differentiation - fixation index $\left(\mathrm{F}_{\mathrm{ST}}\right)$ and gene flow among Anopheles nuneztovari s.l. collected from Antioquia and Córdoba, Colombia

\begin{tabular}{lcccc}
\hline & \multicolumn{3}{c}{ Cytochrome oxidase subunit I } \\
\cline { 2 - 5 } Localities & Puerto Libertador & Montelíbano & El Bagre and Zaragoza & San Pedro de Urabá \\
\hline Puerto Libertador & - & $\infty$ & 6.02 & 4.09 \\
Montelíbano & -0.02020 & - & 6.88 & 3.13 \\
El Bagre and Zaragoza & 0.07657 & 0.06767 & - & 3.12 \\
San Pedro de Urabá & 0.10872 & 0.13743 & 0.13778 & - \\
\hline
\end{tabular}

above diagonal: Nm value; below diagonal: $\mathrm{F}_{\mathrm{ST}}$ values; $\infty$ : infinity. $\mathrm{p}<0.05$. 
localities (populations), as one group showed that $12.49 \%$ $(\mathrm{p}=0.18)$ of the variance, could be attributed to among localities (populations) and $87.51 \%$ within (Table IV).

The COI network showed a single most common haplotype (type $1, n=55$ ), which was present in all the localities. There were only 16 private haplotypes, which demonstrates high demographic stability and the existence of gene flow among populations (Fig. 2). After removing the intron sequence, a $630 \mathrm{bp}$ fragment of the nuclear white gene was analyzed. From 20 sequences obtained, the consensus sequence was submitted to GenBank with accession JN255772. Phylogenetic neighbour-net network based on white gene sequences showed that An. nuneztovari s.l. specimens from Antioquia and Córdoba grouped with haplotypes 19 and 20, which are part of lineage 3, as reported by Mirabello and Conn (2008). However, the Bayesian analysis was completely unresolved and uninformative; whereas the neighbournet network had an area of boxes, which indicated the need for larger sample sizes from these regions.

\section{DISCUSSION}

The results obtained with $C O I$ sequences of specimens An. nuneztovari s.l. collected in localities of high malaria transmission of Antioquia and Córdoba showed low genetic differentiation and gene flow among these localities. In general, levels of $C O I$ nucleotide diversity were higher for the populations of Antioquia than for populations of Córdoba. Further, most haplotypes were shared between both regions, suggesting that these populations have a common demographic history (Castelloe \& Templeton 1994) (Fig. 2). Avise (2000) proposed that populations with high nucleotide and Hd are more stable, constant in size and have higher effective population sizes. In this study, An. nuneztovari s.l. from SPU had the highest nucleotide and $\mathrm{Hd}$, indicating that this popu-

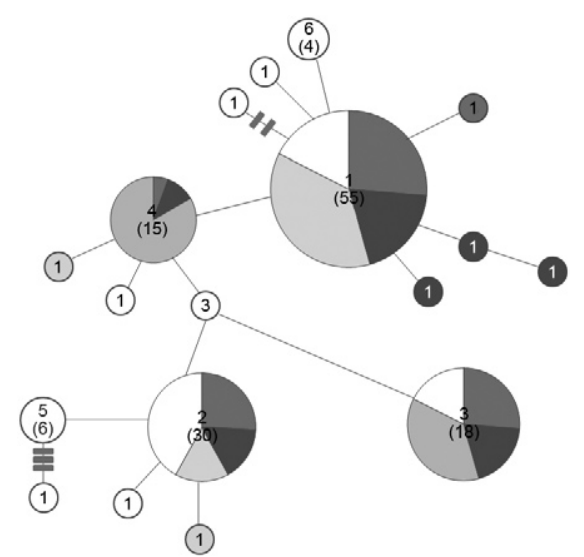

Fig. 2: parsimony based haplotype network of 20 cytochrome oxidase subunit I haplotypes of 147 Anopheles nuneztovari s.l. specimens. Each locality is represented by a distinct shade. Numbers out of the parentheses represent the haplotype designation and those inside the parentheses indicate the number of sequences included in each haplotype. The size of the circle is proportional to the frequency of detected haplotype. BAG: El Bagre; MTL: Montelíbano; PTL: Puerto Libertador; SPU: San Pedro de Urabá; ZAR: Zaragoza. lation is the most stable among the populations studied. $\mathrm{F}_{\mathrm{ST}}$ and $\mathrm{Nm}$ values obtained suggest that An. nuneztovari s.l. from Antioquia and Córdoba may actually comprise a single population. $\mathrm{Nm}$ values in malaria vectors are of relevance because they can be used to predict gene spread, e.g. of those genes important for insecticide resistance or parasite refractoriness. An understanding of gene flow is essential for the introduction of transgenic mosquitoes carrying genes for Plasmodium resistance.

White gene phylogenetic analyses of samples from Antioquia and Córdoba together with other South American populations produced mixed results. Our sequences were identical to haplotypes 19 and 20 reported by Mirabello and Conn (2008), which corresponded to their lineage 3 . The area of boxes in the neighbour-net network combined with the unresolved Bayesian analysis, suggest that a broader sampling of this species complex with analyses of white gene and other nuclear genes should be undertaken to more formally test the five lineages proposed in Mirabello and Conn (2008). Nevertheless, our results are consistent with previous studies with various markers that detected differentiation between An. nuneztovari s.l. populations from Colombia and Venezuela west of the Andes with those in other regions of South America (Elliott 1972, Kitzmiller et al. 1973, Conn et al. 1993, Fritz et al. 1994, Scarpassa et al. 1996, 1999, 2000 , Mirabello \& Conn 2008, Scarpassa \& Conn 2011).

In comparison with the results presented here, a study using the rDNA ITS2 suggested low differentiation between An. nuneztovari s.l. populations located on opposite sides of the Andes mountains (northwest and northeast Colombia), indicating that An. nuneztovari s.l. is conspecific in Colombia (Sierra et al. 2004). Further, a study using RAPD markers showed low levels of genetic differentiation for An. nuneztovari s.l. populations from northwest and northeast Colombia, with higher levels of gene flow among western populations (Posso et al. 2003). Although Posso et al. (2003) used RAPD for discrimination of populations in western Colombia their results are in agreement with the ones in the present study with COI, also in western Colombia. Collectively, results of these studies with An. nuneztovari s.l. populations from northwest and northeast Colombia are consistent in the detection of low genetic differentiation among the populations evaluated.

Localities in the present study are placed in the Magdalena biogeographic province (Morrone 2006),

\section{TABLE IV}

Analysis of molecular variance of Anopheles nuneztovari s.1. based on cytochrome oxidase subunit I haplotypes

\begin{tabular}{lccc}
\hline Source of variation & $\begin{array}{c}\text { Variance } \\
\text { components }\end{array}$ & $\begin{array}{c}\text { Variation } \\
(\%)\end{array}$ & $\begin{array}{c}\text { Fixation } \\
\text { index }\end{array}$ \\
\hline Among populations & 0.1896 & 12.49 & $0.12^{a}$ \\
Within populations & 1.3234 & 87.51 & - \\
\hline
\end{tabular}

$a$ : not significant $(\mathrm{p}>0.05)$. 
which encompasses western Venezuela and northwest Colombia. The Magdalena province is characterized by temperatures above $24^{\circ} \mathrm{C}$, plains with altitudes no greater than $500 \mathrm{~m}$, fragmented forest, presence of livestock and agriculture and active mining (IGAC 2002). The concurrence of similar ecologic and geographic conditions in this biogeographic region may influence $A n$. nuneztovari s.l. populations, favouring the low genetic differentiation observed. The location of An. nuneztovari s.l. cytotypes $\mathrm{B}$ and $\mathrm{C}$ coincide with the Magdalena biogeographic province, while cytotype A was reported in the Brazilian Amazon, south of the country. Given that An. nuneztovari s.l. is broadly distributed in Colombia, including regions in the south in close proximity to the Brazilian Amazon, genetic analyses of An. nuneztovari s.l. should be expanded to include specimens from the southern regions such as the Orinoquía and the Amazonia, and other markers such as microsatellites to detect recent mutational events.

Previous work by our group evaluated microgeographic genetic variation of An. darlingi, another important Colombian malaria vector, in Antioquia and Córdoba. Those results were based on microsatellites and $\mathrm{COI}$ analysis and also showed that An. darlingi populations were highly homogeneous and presented high levels of gene flow (Gutiérrez et al. 2010). In the report presented here, microsatellite analysis was not performed because at the time of our collections and analyses, these markers had not been available for An. nuneztovari (Cardoza et al. 2011). It is possible that microsatellite analysis of An. nuneztovari, as with An. darlingi, would have revealed low genetic differentiation and high gene flow. In particular, analyses of An. darlingi in Brazil at the microgeographic level (152 km apart) showed low levels of genetic differentiation $\left(\mathrm{F}_{\mathrm{ST}}=0.001-0.095\right)$ and $\mathrm{Nm}$ values between $4.7-$ 363.8 , indicating that at this distance and within similar ecological and geographic conditions, anopheline differentiation may be low (Scarpassa \& Conn 2007). Howev-

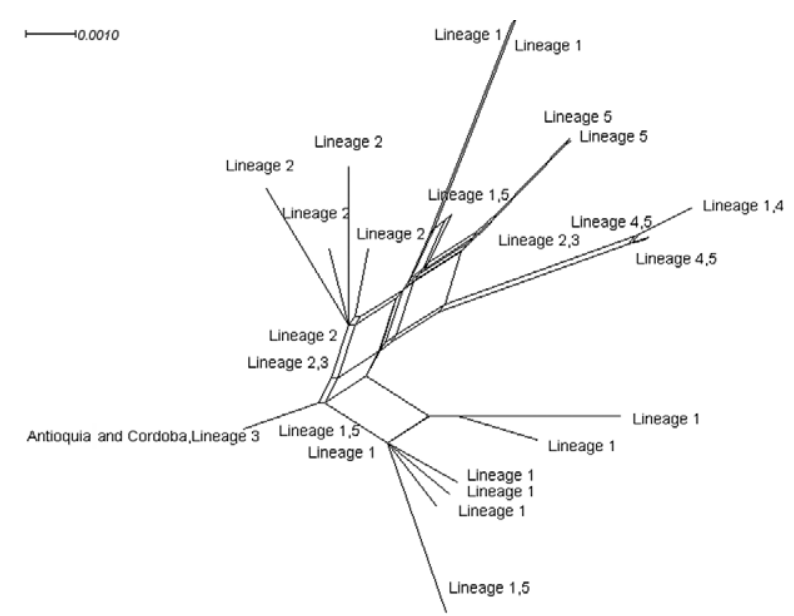

Fig. 3: neighbour-net network of Anopheles nuneztovari s.l. white gene lineages from Antioquia and Córdoba compared with other $\mathrm{An}$. nuneztovari s.l from South America. er, differentiation at the microgeographic level has been documented for other important malaria vectors such as Anopheles gambiae (McLain et al. 1989). Specifically, in seven Kenyan localities less than $10 \mathrm{~km}$ apart, the authors found significant differences in the genetic distribution of this important African vector, indicating the absence of gene flow, probably due to poor dispersal abilities of these populations (McLain et al. 1989).

In summary, the results obtained in the present study provide critical data for understanding the primary malaria vector An. nuneztovari s.l. in localities with the highest annual reports of malaria cases in Colombia (Rodríguez et al. 2011). In particular, the presence of low genetic differentiation and high gene flow for important malaria vector species, such as $A n$. darlingi and $A n$. nuneztovari s.l., indicate that malaria control programs could apply the same strategies, for example insecticide spraying, in these localities of Antioquia and Córdoba, as has been previously suggested (Gutiérrez et al. 2010).

\section{ACKNOWLEDGEMENTS}

To G Gómez, M Altamiranda, N Naranjo and A Yates, who cooperated in specimen collection and identification, to Sara A Bickersmith, Wadsworth Centre, New York State Department of Health, Albany, NY, for preliminary manuscript evaluation and critical editorial comments.

\section{REFERENCES}

Arruda M, Carvalho MB, Nussenzweig RS, Maracic M, Ferreira AW, Cochrane AH 1986. Potential vectors of malaria and their different susceptibility to Plasmodium falciparum and Plasmodium vivax in northern Brazil identified by immunoassay. Am J Trop Med Hyg 35: 873-881.

Avise J 2000. Phylogeography: the history and formation of species, Harvard University Press, London, $447 \mathrm{pp}$.

Bergo ES, Souto RN, Galardo AK, Nagaki SS, Calado DC, Sallum MA 2007. Systematic notes on Anopheles Meigen (Diptera: $\mathrm{Cu}-$ licidae) species in the state of Amapá, Brazil. Mem Inst Oswaldo Cruz 102: 373-376.

Calado DC, Foster PG, Bergo ES, Santos CLS, Galardo AK, Sallum MA 2008. Resurrection of Anopheles goeldii from synonymy with Anopheles nuneztovari (Diptera, Culicidae) and a new record for Anopheles dunhami in the Brazilian Amazon. Mem Inst Oswaldo Cruz 103: 791-799.

Calle DA, Quiñones ML, Erazo HF, Jaramillo N 2008. Discriminación por morfometría geométrica de once especies de Anopheles (Nyssorhynchus) presentes en Colombia. Biomedica 28: 371-385.

Cardoza TB, Barbosa De Sousa AC, Prado Lima M, Pereira De Souza A, Scarpassa VM 2011. Microsatellite markers for the neotropical malaria vector Anopheles nuneztovari sensu lato: isolation, development and characterization of eighteen loci. Mol Ecol Resources. Available from: tomato.bio.trinity.edu/ manuscripts/11-4/mer-11-0032.pdf.

Castelloe J, Templeton A 1994. Root probabilities for intraspecific gene trees under neutral coalescent theory. Mol Phylogenet Evol 3: 102-113.

Cienfuegos A, Gómez G, Córdoba L, Luckhart S, Conn J, Correa M 2008. Diseño y evaluación de metodologías basadas en PCRRFLP de ITS2 para la identificación molecular de mosquitos Anopheles spp (Diptera: Culicidae) de la Costa Pacífica de Colombia. Rev Biomed 19: 35-44.

Cienfuegos AV, Rosero DA, Naranjo N, Luckhart S, Conn JE, Correa MM 2011. Evaluation of a PCR-RFLP-ITS2 assay for discrimi- 
nation of Anopheles species in northern and western Colombia. Acta Trop 118: 128-135.

Clement M, Posada D, Crandall KA 2000. TCS: a computer program to estimate gene genealogies. Mol Ecol 9: 1657-1659.

Conn J, Puertas Y, Seawright J 1993. A new cytotype of Anopheles nuneztovari from western Venezuela and Colombia. J Am Mosq Control Assoc 9: 294-301.

Drummond AJ, Ashton B, Buxton S, Cheung M, Cooper A, Duran C, Field M, Heled J, Kearse M, Markowitz S, Moir R, Stones-Havas S, Sturrock S, Thierer T, Wilson A 2011. Research software for biologists, not computer scientists. Available from: geneious.com.

Elliott R 1972. The influence of vector behaviour on malaria transmission. Am J Trop Med Hyg 21: 755-763.

Excoffier L, Laval G, Schneider S 2005. Arlequin ver. 3.0: an integrated software package for population genetics data analysis. Evol Bioinform Online 1: 47-50.

Faran M, Linthicum K 1981. A handbook of the Amazonian species of Anopheles (Nyssorhynchus) (Diptera: Culicidae). Mosq Syst 13: $1-81$.

Faran ME 1980. Mosquito studies (Diptera: Culicidae) XXXIV. A revision of the Albimanus section of the subgenus Anopheles Nyssorhynchus (Diptera: Culicidae). Am Ent Inst 15: 1-215.

Fritz G, Conn J, Cockburn A, Seawright J 1994. Sequence analysis of the ribosomal DNA internal transcribed spacer 2 from populations of Anopheles nuneztovari (Diptera: Culicidae). Mol Biol Evol 11: 406-416.

Galardo AK, Arruda M, D’Almeida Couto AA, Wirtz R, Lounibos LP, Zimmerman RH 2007. Malaria vector incrimination in three rural riverine villages in the Brazilian Amazon. Am J Trop Med Hyg 76: 461-469.

Gómez G, Cienfuegos A, Gutiérrez L, Conn J, Correa M 2010. Análisis morfológico y molecular evidencia problemas al identificar Anopheles nuneztovari (Diptera: Culicidae) por claves dicotómicas. Rev Col Entomol 36: 68-75.

González R, Carrejo N 2009. Introducción al estudio taxonómico de Anopheles de Colombia: claves y notas de distribución, 2nd ed, Programa Editorial Universidad de Valle, Cali, 260 pp.

Gutiérrez LA, Gomez GF, Gonzalez JJ, Castro MI, Luckhart S, Conn JE, Correa MM 2010. Microgeographic genetic variation of the malaria vector Anopheles darlingi Root (Diptera: Culicidae) from Córdoba and Antioquia, Colombia. Am J Trop Med Hyg 83: 38-47.

Gutiérrez LA, González JJ, Gómez GF, Castro MI, Rosero DA, Luckhart S, Conn JE, Correa MM 2009a. Species composition and natural infectivity of anthropophilic Anopheles (Diptera: Culicidae) in the states of Córdoba and Antioquia, northwestern Colombia. Mem Inst Oswaldo Cruz 104: 1117-1124.

Gutiérrez LA, Naranjo NJ, Cienfuegos AV, Muskus CE, Luckhart S, Conn JE, Correa MM 2009b. Population structure analyses and demographic history of the malaria vector Anopheles albimanus from the Caribbean and the Pacific regions of Colombia. Malar J 8: 259.

Huelsenbeck JP, Ronquist F 2001. MRBAYES: Bayesian inference of phylogenetic trees. Bioinformatics 17: 754-755.

Huson DH, Bryant D 2006. Application of phylogenetic networks in evolutionary studies. Mol Biol Evol 23: 254-267.

Huson DH, Steel M 2004. Phylogenetic trees based on gene content. Bioinformatics 20: 2044-2049.

IGAC - Instituto Geográfico Agustín Codazzi 2002. Atlas de Colombia, 5th ed., Imprenta Nacional de Colombia, Bogotá, 342 pp.

Kitzmiller J, Kreutzer R, Tallaferro E 1973. Chromosomal differences in populations of Anopheles nuneztovari. Bull World Health Org 48: 435-445.
Lounibos L, Conn J 2000. Malaria vector heterogeneity in South America. Am Entomol 46: 238-249.

Lunt DH, Zhang DX, Szymura JM, Hewitt GM 1996. The insect cytochrome oxidase I gene: evolutionary patterns and conserved primers for phylogenetic studies. Insect Mol Biol 5: 153-165.

McLain DK, Collins FH, Brandling-Bennett AD, Were JB 1989. Microgeographic variation in rDNA intergenic spacers of Anopheles gambiae in western Kenya. Heredity 62: 257-264.

Mirabello L, Conn JE 2008. Population analysis using the nuclear white gene detects Pliocene/Pleistocene lineage divergence within Anopheles nuneztovari in South America. Med Vet Entomol 22: 109-119.

Montoya-Lerma J, Solarte YA, Giraldo-Calderón GI, Quiñones ML, Ruiz-López F, Wilkerson RC, González R 2011. Malaria vector species in Colombia - A Review. Mem Inst Oswaldo Cruz 106 (Suppl. I): 223-238.

Morrone JJ 2006. Biogeographic areas and transition zones of Latin America and the Caribbean islands based on panbiogeographic and cladistic analyses of the entomofauna. Annu Rev Entomol 51: 467-494.

Olano VA, Brochero HL, Sáenz R, Quiñones ML, Molina JA 2001. Mapas preliminares de la distribución de especies de Anopheles vectores de malaria en Colombia. Biomedica 21: 402-408.

Onyabe D, Conn J 1999. Intragenomic heterogeneity of a ribosomal DNA spacer (ITS2) varies regionally in the neotropical malaria vector Anopheles nuneztovari (Diptera: Culicidae). Insect Mol Biol 8: 435-442.

OPS - Organización Panamericana de la Salud 2009. Informe de la situación del paludismo en las Américas, OPS, Washington, 9 pp.

Posso CE, González R, Cárdenas H, Gallego G, Duque MC, Suarez MF 2003. Random amplified polymorphic DNA analysis of Anopheles nuneztovari (Diptera: Culicidae) from western and northeastern Colombia. Mem Inst Oswaldo Cruz 98: 469-476.

Ramos MF, Obando RG, Suárez MF, López D, Wilkerson R, Sallum MA 2008. Morphological analysis of three populations of Anopheles (Nyssorhynchus) nuneztovari Gabaldón (Diptera: Culicidae) from Colombia. Mem Inst Oswaldo Cruz 103: 85-92.

Rodríguez JC, Uribe GA, Araújo RM, Narváez PC, Valencia SH 2011. Epidemiology and control of malaria in Colombia. Mem Inst Oswaldo Cruz 106 (Suppl. I): 114-122.

Rosero D, Gutiérrez L, Cienfuegos A, Jaramillo L, Correa M 2010. Optimización de un procedimiento de extracción de ADN para mosquitos anofelinos. Rev Col Entomol 36: 260-263.

Rozas J, Sanchez-DelBarrio J, Messeguer X, Rozas R 2003. DnaSP, DNA polymorphism analyses by the coalescent and other methods. Bioinformatics 19: 2496-2497.

Rubio-Palis Y, Curtis C 1992. Biting and resting behaviour of anophelines in western Venezuela and implications for control of malaria transmission. Med Vet Entomol 4: 325-334.

Scarpassa V, Tadei W, Suarez M 1996. Alloenzyme differentiation among allopatric populations of Anopheles nuneztovari (Diptera: Culicidae). Braz J Genet 19: 265-269.

Scarpassa VM, Conn JE 2007. Population genetic structure of the major malaria vector Anopheles darlingi (Diptera: Culicidae) from the Brazilian Amazon using microsatellite markers. Mem Inst Oswaldo Cruz 102: 319-327.

Scarpassa VM, Conn JE 2011. Mitochondrial DNA detects a complex evolutionary history with pleistocene epoch divergence for the neotropical malaria vector Anopheles nuneztovari sensu lato. Am J Trop Med Hyg 85: 857-867. 
Scarpassa VM, Geurgas S, Azeredo-Espin AM, Tadei WP 2000. Genetic divergence in mitochondrial DNA of Anopheles nuneztovari (Diptera: Culicidae) from Brazil and Colombia. Genet Mol Biol 23: 71-78.

Scarpassa VM, Tadei WP, Suarez MF 1999. Population structure and genetic divergence in Anopheles nuneztovari (Diptera: Culicidae) from Brazil and Colombia. Am J Trop Med Hyg 60: 1010-1018.

Sierra DM, Velez ID, Linton YM 2004. Malaria vector Anopheles (Nyssorhynchus) nuneztovari comprises one genetic species in Colombia based on homogeneity of nuclear ITS2 rDNA. J Med Entomol 41: 302-307.
Tadei WP, Thatcher B, Santos JM, Scarpassa VM, Rodrigues IB, Rafael MS 1998. Ecologic observations on anopheline vectors of malaria in the Brazilian Amazon. Am J Trop Med Hyg 59: 325-335.

Tadei WP, Thatcher DB 2000. Malaria vectors in the Brazilian Amazon: Anopheles of the subgenus Nyssorhynchus. Rev Inst Med Trop Sao Paulo 42: 87-94.

Zapata MA, Cienfuegos AV, Quiros OI, Quinones ML, Luckhart S, Correa MM 2007. Discrimination of seven Anopheles species from San Pedro de Urabá, Antioquia, Colombia, by polymerase chain reaction-restriction fragment length polymorphism analysis of its sequences. Am J Trop Med Hyg 77: 67-72. 